\title{
Peningkatan Nilai Ekonomi Peternak Melalui Diversifikasi Usaha Sapi Perah
}

\author{
(IMPROVEMENT OF FARMERS ECONOMIC VALUE \\ THROUGH DIVERSIFICATION OF DAIRY COW BUSINESS)
}

\author{
Supardi Rusdiana, Lisa Praharani, \\ Andi B Lompengeng Ishak, Chalid Talib
}

\author{
Balai Penelitian Ternak, Ciawi, Bogor \\ Jl. Banjarwaru, Kotak Pos 221, Ciawi, \\ Bogor, Jawa Barat, Indonesia 16720 \\ Email: s.rusdiana20@gmail.com \\ Telp.0251-8240751-8240753
}

Fax.0251-8240754

\begin{abstract}
ABSTRAK
Tujuan penelitian adalah untuk mengetahui peningkatan nilai ekonomi peternak melalui diversifikasi usaha sapi perah. Penelitian dilakukan di Desa Cikahuripan, Cikole, Cikidang dan Cibogo, Kecamatan Lembang, Kabupaten Bandung Barat, Jawa Barat tahun 2019. Penelitian menggunakan metode survei dengan teknik wawancara dan pengisian kuisioner terhadap 100 peternak. Peternak pada penelitian ini adalah peternak sapi perah, yang berasal dari empat desa. Dari setiap desa yang dijadikan sebagai reapondens/sampel sebanyak 25 peternak (total sampling). Data primer dan data sekunder dianalisis secara deskriptif, kantitatif, statistika dan analisis ekonomi. Hasil penelitian menunjukkan rata-rata produksi susu sapi perah laktasi dan produksi jagung yang dihasilkan oleh peternak, di setiap desa tidak sama, disebabkan skala usaha dan modal yang berbeda. Rata-rata peternak memanfaatkan limbah jerami jagung sebanyak 18,5\% peternak, sisanya limbah pertanian dan pakan lainnya. Dukungan pakan dari limbah jerami jagung dapat memenuhi kebutuhan pakan sapi perah sehari-hari serta dapat mengurangi biaya produksi pakan. Rata-rata nilai keuntungan dari usaha sapi perah di peternak R/C 1,50 , dan rata-rata nilai keuntungan dari usaha jagung di peternak R/C 1,41. Simpulan yang dapat ditarik bahwa diversifikasi usaha sapi perah dan jagung di peternak nilai $\mathrm{R} / \mathrm{C}>1$, usaha tersebut layak untuk dilanjutkan.
\end{abstract}

Kata-kata kunci: peningkatan ekonomi; diversifikasi usaha; peternak; sapi perah

\begin{abstract}
The research objective was to determine the increase in the economic value of farmers through the diversification of the dairy cows bussiness. The research was conducted in the villages of Cikahuripan, Cikole, Cikidang and Cibogo, Lembang District, West Bandung Regency, West Java Province in 2019. The research used a survey method with interview techniques and questionnaires to 100 farmers. Farmers in this study were dairy farmers, which were taken from four villages, where each village was used as a sample of 25 farmers (total sampling). Primary data and secondary data were analyzed by descriptive, quantitative, statistical and economic analysis. The results showed that the average milk production of lactating dairy cows and the production of maize produced by farmers was not the same in each village, due to different business scales and capital. On average, $18.5 \%$ of farmers use corn straw waste, the rest is agricultural waste and other feed. The average value of profits from dairy farming in R/C farmers is 1.50 , and the average value of profits from corn businesses in RC farmers is 1.41 . In conclusion, through the diversification of dairy cattle and corn farms with an $\mathrm{R} / \mathrm{C}$ value of $>1$, it is feasible to continue their business.
\end{abstract}

Keywords: economic improvement; business diversification; farmers; dairy cow 


\section{PENDAHULUAN}

Berdasarkan sosial, ekonomi, budaya dan lingkungan masyarakat di Kabupaten Bandung Barat, Jawa Barat, selain usaha pertanian juga usaha sapi perah yang telah lama diusahakan oleh peternak seperti di Kecamatan Lembang, Kabupaten Bandung Barat (Nainggolan dan Erniwaty, 2017). Usaha peternak tersebut merupakan usaha diversifikasi sapi perah yang menguntungkan pada berbagai tingkat skala usaha, sehingga dapat menambah nilai pendapatan ekonomi peternak setiap tahunnya. Usaha utama yang dilakukan oleh peternak kecil pedesaan adalah usaha pertanian tanaman pangan dalam arti luas dan usaha sampingan adalah usaha sapi perah yang berharap dapat menopang dana tambahan kebutuhan rumah tangga sehari-hari serta sebagai tabungan. Secara umum, diversifikasi adalah perluasan usaha yang dapat dilakukan oleh peternak atau oleh pengusaha, sehingga sangat penting untuk dilakukan, agar usaha menjadi lebih menguntungkan, manfaat diversifikasi untuk meminimalisir risiko kerugian dari suatu investasi, selain itu bisa juga memberikan keuntungan yang lebih maksimal

Melalui usaha diversifikasi, peternak mendapat keuntunagn ganda yang diperoleh dari hasil produksi sapi perah dan hasil tanaman pangan dan hasil lainnya. Pentingnya dukungan Pemerintah Pusat dan Daerah, penyuluh pertanian, peternakan dan inseminator, baik dari Dinas Peternakan setempat maupun dari Koperasi susu, sehingga usaha sapi perah milik peternak bisa lebih mapan dan meningkat. Dukungan tersebut sangat berpengaruh nyata pada peningkatan usaha sapi perah dan usaha pertanian. Perbaikan manajemen, perawatan kesehatan, teknologi, infrastuktur dan dukungan kebijakan Pemerintah, Pusat dan Daerah terus diarahkan pada usaha sapi perah milik peternak (Wardani et al., 2012). Dasar pemikiran peternak adalah dapat memanfaatkan limbah hasil tanaman pangan, seperti tanaman jagung, sebagai pakan sapi perah yang dapat mengurangi biaya produksi untuk pembelian pakan konsentrat. Sebagain besar peternak mempunyai lahan pertanian, ladang, lahan kosong dan tegalan dapat dimanfaatkan sebagai lahan untuk kandang dan budidaya hijauan pakan sapi perah (Rusdiana et al., 2019), dan pada umunya peternak sapi perah bergabung dalam wadah koperasi sapi perah.

Hasil produksi susu sapi perah di peternak disalurkan ke Koperasi Lembang, sehingga peternak tidak kesulitan dalam memasarkan hasil produk susunya, termasuk jual-beli ternaknya seperti pedet, pejantan dan induk afkir. Terbukanya usaha sapi perah dan tanaman pangan di lokasi peternak, selain pemasarannya yang mudah juga menjadi salah satu peluang besar bagi peternak untuk mengembangkan usaha sapi perah dan pertanian. Sapi perah menjadi ikon bagi masyarakat Kabupaten Bandung Barat, dan sebagai lokasi produksi makanan dari produksi susu sapi perah. Secara tidak langsung usaha sapi perah, mampu memperbaiki perekonomian masyarakat peternak, dari hasil usaha sapi perah dan pertanian. Pertanian tanaman pangan seperti jagung dan tanaman lainnya, yang sering diusakan oleh peternak, selain produksi jagung yang dapat dijual ke pasar juga limbah jerami jagung di manfaatkan sebagai pakan sapi perah. Tanaman jagung biasanya ditanam oleh peternak antara 2-3 kali tanam/ panen dalam satu tahun.

Hasil produksi susu sapi perah yang dihasilkan oleh peternak setiap hari dan bisa untuk biaya hidup peternak sehari-hari. Dengan demikian usaha sapi perah banyak diminati oleh masyarakat sekitar, karena selain dapat dipelihara dengan teknologi yang sederhana, juga hasil produksi susu dapat menyumbangkan pendapatan harian bagi peternak. Secara sosial ekonomi dan budaya peternak, usaha sapi perah dan tanaman jagung dapat meningkatkan pendapatan peternak dan sebagai usaha pokok. Diversifikasi usaha sapi perah dan tanaman jagung sudah sering dilakukan dan dikenal sebagai crop-livetock system (CLS). Pada saat ini CLS sudah banyak dikembangkan di berbagai wilayah di Indonesia dan juga negara Asia (Diwyanto et al., 2002). Kenyataan di lapangan usaha sapi perah di peternak belum banyak mengarah pada usaha yang bersifat komersial, hanya sebatas usaha sampingan dan tabungan (Rusdiana dan Praharani, 2020). Menurut Asmara et al. (2016) persoalan lain pada usaha sapi perah di samping masih rendah skala usahanya, juga tingkat efisiensi usaha masih belum terukur dengan biaya produksi yang dikeluarkan oleh peternak.

Walaupun usaha sapi perah masih rendah, namun peternak terus berupaya untuk meningkatkannya, melalui perbaikan pakan yang berkualitas, bibit induk produktif dan pejantan unggul. Peternak sapi perah belum mendapat keuntungan yang optimal, karena 
biaya untuk pembelian pakan masih cukup tinggi. Untuk menutupi kekurangan biaya usaha, maka peternak menggunakan cara lain, yaitu melalui pembesaran jantan dan penggemukan sapi induk afkir. Sapi jantan dan induk afkir yang digemukkan atau dibesarkan selama waktu tertentu, mempunyai nilai jual yang cukup tinggi. Sehingga peternak dapat menutupi biaya produksi untuk pakan dan baya lainnya yang tidak terduga. Penjualan selain dari hasil produksi susu sapi perah, juga dari pedet, jantan dam induk afkir yang sudah tidak bisa berproduksi lagi. Produksi dan reproduksi pada sapi perah sangat berkaitan erat dengan perkembangan sapi perah dan tersedianya jaminan harga pasar ternak dan harga pasar susu sapi perah.

Usaha sapi perah banyak dilakukan secara intensif dengan cara sapi perah dikandangkan terus menerus, karena sapi perah mempunyai sifat sebagai penerimaan uang harian dari hasil produksi susu. Induk sapi perah dan calon induk, selain dapat diperoleh keturunannya sifat dari kedua tetuanya juga dapat memperpendek interval generasi penerus. Selain itu untuk perbaikan mutu genetik ternak bisa lebih cepat diperoleh dan dapat meningkatkan produksi sapi perah, karena dalam hal ini diperlukan seleksi bibit. Sapi perah pedet betina yang dihasilkan dapat dipelihara untuk meneruskn keturunan berikutnya dan dapat meningkatkan populasi sapi perah. Saat ini sapi perah masih menjadi mata pencaharian yang dominan bagi peternak, karena sapi-sapi tersebut menghasilkan produksi susu harian. Namun, usaha tersebut belum banyak mempertimbangkan aspek keuntungan di tingkat peternak. Salah satu caranya adalah dengan melakukan pengaturan perkawinan sapi perah masih terlambat, karena kemungkinan induk-induk sapi tersebut bitahinya lambat.

Sapi perah dapat diklasifikasikan dan menurut skala usaha terdiri dari atas perusahaan peternakan sapi perah dan usaha peternakan sapi perah rakyat (Simamora et al., 2015). Berdasarkan permasalahan tersebut, secara umum usaha sapi perah di Kecamatan Lembang masih tradisional dan belum beorientasi komersial, terlihat dari skala usaha yang memelihara 2-4 ekor sapi perah per peternak. Hal tersebut disebabkan karena faktor modal, persaingan harga ternak, sehingga peternak menganggap usaha sapi perah sebagai usaha sampingan (Nainggolan dan Erniwaty, 2017). Untuk itu pemberdayaan peternak perlu dilakukan melalui diversifikasi usaha, sehingga pendapatan peternak bukan hanya dari hasil produksi sapi perah saja, malainkan juga dari hasil pertanian. Wilayah Kecmatan Lembang Kabupaten Bandung Barat mempunyai peranan yang cukup besar dalam pembangunan perekonomin, dan salah satunya usaha sapi perah dan tanaman pangan. Tujuan penelitian ini adalah untuk mengetahui peningkatan nilai tambah ekonomi peternak melalui diversifikasi usaha sapi perah di tingkat peternak, sehingga penelitian ini perlu dilakukan.

\section{METODE PENELITIAN}

\section{Waktu dan Tempat Penelitian}

Penelitian dilakukan di Desa Cikahuripan, Cikole, Cikidang dan Cibogo Kecamatan Lembang Kabupaten Bandung Barat. Penelitian menggunakan pendekatan expost facto research yang dilaksanakan tahun 2019. Lokasi penelitian dipilih secara sengaja (purposive) dengan pertimbangan bahwa Kecamatan Lembang Kabupaten Bandung Barat merupakan Kabupaten pengembangan usaha sapi perah dan usaha pertanian, yang tersebar di 16 Desa. Namun yang diambil sebagai sampel penelitian adalah 4 Desa, dimana setiap Desa sebagai binaan Dinas Perikanan dan Peternakan Kabupaten Bandung Barat dan Koperasi KPSBU, Lembang Bandung Barat.

\section{Analisis Data}

Data penelitian diperoleh melalui metoda survai dan pengamatan langsung terhadap 100 peternak sapi perah dengan teknik wawancara dan pengisian kuisioner. Responden pada penelitian ini adalah peternak sapi perah, dimana masing-masing Desa dijadikan sebagai sampel sebanyak 25 peternak (total sampling), sehingga memudahkan identifikasi masalah utama usaha sapi perah. Sampel ini merupakan bagian dari jumlah responden yang menjadi sumber data, pengambilan sampel dilakukan dengan teknik stratified random sampling (Amam dan Harsita, 2019). Data primer diperoleh hasil wawancara langsung dilapangan dengan responden, yang mengacu kepada kuisioner. Sedangkan data sekunder diperoleh dari Dinas Perikanan dan Peternakan Kabupaten Bandung Barat dan Koperasi KPBSU Lembang, serta data dukung lainnya. Data primer dan data sekunder dinalisis secara deskriptif, kuantitatif, statistik dan analisis 
ekonomi. Analisis ekonomi usaha sapi perah sangat perlu dilakukan, karena secara umum, teknik usaha dapat di ukur tingkat kemampuan usaha, tingkat penggunaan biaya produksi dan sumber daya manusia serta modal.

Sumber daya internal yaitu, sumber daya finansial, sumber daya teknologi dan sumber daya fisik yang dapat diukur oleh kemampuan secara fisik dan terukur dengan kondisi yang ada (Syukur et al., 2014). Keuntungan maksimum dapat dicapai pada saat nilai produksi marjinal dari masing-masing masukan sama dengan biaya marjinalnya. Untuk melihat keterkaitan antara faktor-faktor produksi yang digunakan, serta dapat dihasilkan baik itu yang menyangkut usaha sapi perah maupun usaha jagung. Fungsi produksi dari usaha dapat dianalisis, apabila produk yang dihasilkan sesuai dengan kondisi usaha. Pada umumnya fungsi froduksi dapat dihitung berdasarkan nilai atau modal awal usaha yang digunakan serta nilai akhir keuntungan, keuntungan kotor dikurangi jumlah biaya produksi. Namun hal tersebut belum sepenuhnya dapat dihitung, karena modal sebagai awal adalah untuk membuat kandang, pembelian bibit peralatan kandang dan lainnya, dapat dihitung sebagai investasi usaha awal. Fungsi produksi pada usaha sapi dan jangung, merupakan suatu fungsi atau persamaan yang melibatkan dua usaha yang mempunyai hubungan variabel berbeda.

Menurut Soekartawi (2002), bentuk dasar yang logis secara fisik dan mudah untuk dianalisis pada setap usaha, dan mempunyai implikasi ekonomi, tentunya perkembangan usaha dapat dihitung pada awal usaha dan pada akhir usaha, begitu pula dengan usaha jagung. Berdasarkan kemampuan dalam menjabarkan hasil produksi yang diperoleh, serta kemudahan dalam memproses usaha maka, dalam pendugaan dapat digunakan sebagai fungsi produksi tipe Cobb-Douglass (Steel dan Torrie, 2000). Analisis Ragam dan senjang hasil digunakan untuk menganalisis dari usaha sapi perah dan usaha jagung, bila berbeda nyata dilanjutkan dengan uji Duncan dan efisiensi atas usaha yang dianalisis secara ekonomi finansial (Steel dan Torrie, 2000). Fungsi tersebut merupakan fungsi perhitungan aljabar yang yang menggambarkan hubungan antara masukan dan keluaran, pada usaha sapi perah dan jagung. Nilai ekonomi usaha sapi perah dan jagung dapat dilihat dari beberapa asumsi nilai jual, nilai beli maupun input output pada saat usaha dilakukan. Dari beberapa variabel yang dapat mempengaruhi nilai ekonomi, dan mudah untuk dianalisis secara ekonomi finansialnya, perlu data produksi yang akurat dan jelas, sehingga dapat dinilai keabsahannya biaya produksi yang dikeluarkan. Beberapa dan analisis diperoleh adalah data infut dan output dari usaha sapi perah dan jagung yang diusahaan selama satu tahun.

\section{Analisis Data}

Sumber daya internal yaitu, sumber daya finansial, sumber daya teknologi dan sumber daya fisik yang dapat diukur oleh kemampuan secara fisik dan terukur dengan kondisi yang ada (Syukur et al., 2014). Keuntungan maksimum dapat dicapai pada saat nilai produksi marjinal dari masing-masing masukan sama dengan biaya marjinalnya. Untuk melihat keterkaitan antara faktor-faktor produksi yang digunakan, serta dapat dihasilkan baik itu yang menyangkut usaha sapi perah maupun usaha jagung. Fungsi produksi dari usaha dapat dianalisis, apabila produk yang dihasilkan sesuai dengan kondisi usaha. Pada umumnya fungsi produksi dapat dihitung berdasarkan nilai atau modal awal usaha yang digunakan serta nilai akhir keuntungan, keuntungan kotor dikurangi jumlah biaya produksi. Namun hal tersebut belum sepenuhnya dapat dihitung, karena modal sebagai awal adalah untuk membuat kandang, pembelian bibit peralatan kandang dan lainnya, dapat dihitung sebagai investasi usaha awal. Fungsi produksi pada usaha sapi dan jagung, merupakan suatu fungsi atau persamaan yang melibatkan dua usaha yang mempunyai hubungan variabel berbeda.

Menurut Soekartawi (2002), bentuk dasar yang logis secara fisik dan mudah untuk dianalisis pada setap usaha, dan mempunyai implikasi ekonomi, tentunya perkembangan usaha dapat dihitung pada awal usaha dan pada kahir usaha, begitu pula dengan usaha jagung. Berdasarkan kemampuan dalam menjabarkan hasil produksi yang diperoleh, serta kemudahan dalam memproses usaha maka, dalam pendugaan dapat digunakan sebagai fungsi produksi tipe Cobb-Douglass (Steel dan Torrie, 2000). Analisis Ragam dan senjang hasil digunakan untuk menganalisis dari usaha sapi perah dan usaha jagung, bila berbeda nyata dilanjutkan dengan uji Duncan dan efisiensi atas usaha yang dianalisis secara ekonomi finansial (Steel dan Torrie, 2000). Fungi tersebut merupakan fungsi perhitungan aljabar yang 
yang menggambarkan hubungan antara masukan dan keluaran, pada usaha sapi perah dan jagung. Nilai ekonomi usaha sapi perah dan jangung dapat dilihat dari beberapa asumsi nilai jual, nilai beli maupun input output pada saat usaha dilakukan. Beberapa dan analisis diperoleh adalah data input dan output dari usaha sapi perah dan jagung yang diusahaan selama satu tahun.

\section{Analisis Regresi Sederhana}

Perbandingan pendapatan dari hasil usaha ternak, menggunakan dua variabel yang berbeda hasil. Untuk menguji kemampuan generalisasi (signifikansi hasil penelitian berupa perbandingan keadaan variabel dari dua rataan sampel (Hermawan 2012). Untuk mengetahui besaran nilai dari variabel-variabel dapat dianalisis secara ekonomi berdasarkan variabelvariabelnya. Setiap variabel dapat diketahui nilai ekonominya, sehingga saling berkaitan dengan hubungan fungsional atau hubungan sebab akibat (kausal). Perlunya menghitung jumlah tenaga kerja peternak yang dikeluarkan setiap usaha. Hasil analisis survey lapang produksi susu sapi perah dan pedet serta produksi jagung, tenaga kerja yang dikeluarkan sebanyak 5-6 jam/hari. Cara perhitungannya adalah konversi waktu karja peternak dalam satu hari dihitung 1 Hok, upah yang dikeluarkan antara sebesar Rp.15.000,Rp.20.000,-/hari/peternak (Rusdiana dan Adawiyah, 2013). Biaya tenaga kerja peternak dapat diasumsikan kedalam biaya pakan, sebagai indikator usaha dengan rumus:

$$
\begin{aligned}
& Y=a+b x \\
& a=\frac{\left(\sum Y-b \sum X\right)}{n} \\
& b=\frac{N \sum X Y-\left(\sum X\right)\left(\sum Y\right)}{N \sum X^{2}-\left(\sum X\right)^{2}}
\end{aligned}
$$

Dimana :

$\mathrm{Y}=$ Pendapatan peternak (sapi perah dan jagung)

$\mathrm{X}=$ Variabel bebas (biaya produksi sapi perah dan jagung)

$\mathrm{a}=$ Nilai konstanta nilai akhir $=0$

$\mathrm{b}=$ Nilai prediksi peningkatan $(+)$ dan nilai prediksi penurunan (-)

\section{Analisis ekonomi}

Perbandingan pendapatan dari hasil usaha yani ternak, menggunakan dua variabel yang berbeda hasil. Untuk menguji kemampuan generalisasi (signifikansi hasil penelitian berupa perbandingan keadaan variabel dari dua rataan sampel (Hermawan, 2012). Untuk mengetahui besaran nilai dari variabel-variabel dapat dianalisis secara ekonmi berdasarkan variabelvariabelnya. Setiap variabel dapat diketahui nilai ekonominya, sehingga saling berkaitan dengan hubungan fungsional atau hubungan sebab akibat (kausal). Perlunya menghitung jumlah tenaga kerja peternak yang dikeluarkan setiap usaha. Hasil analisis survey lapang produksi susu sapi perah dan pedet serta produksi jagung, tenaga kerja yang dikeluarkan sebanyak 5-6 jam/hari. Cara perhitungannya adalah konversi waktu karja peternak dalam satu hari dihitung 1 Hok, upah yang dikeluarkan antara sebesar Rp.15.000,Rp.20.000,-/hari/peternak (Rusdiana dan Adawiyah, 2013). Biaya tenaga kerja peternak dapat diasumsikan kedalam biaya pakan, sebagai indikator usaha dengan rumus:

$$
\begin{aligned}
& Y=a+b x \\
& a=\frac{\left(\sum Y-b \sum X\right)}{n} \\
& b=\frac{N \sum X Y-\left(\sum X\right)\left(\sum Y\right)}{N \sum X^{2}-\left(\sum X\right)^{2}}
\end{aligned}
$$

Dimana :

$\mathrm{Y}=$ Pendapatan peternak (sapi perah dan jagung)

$\mathrm{X}=$ Variabel bebas (biaya produksi sapi perah dan jagung)

$\mathrm{a}=$ Nilai konstanta nilai akhir $=0$

$\mathrm{b}=$ Nilai prediksi peningkatan $(+)$ dan nilai prediksi penurunan (-)

\section{Analisis Ekonomi}

Kemampuan menghasilkan output pada suatu tingkat kualitas tertentu dengan biaya yang lebih rendah dan memanfaatkan pakan lokal. Efisiensi ekonomi merupakan kombinasi efisiensi teknik dan efisiensi harga. Efisiensi biaya produksi yang dapat dibandingkan dengan perolehan pendapaan selama satu tahun. Untuk mengetahui berapakah manfaat (benefit) serta biaya-biaya (cost), selama umur ekonomis usaha sapi perah dan jagung (in the future) (Seokartawi 2002; Mandaka et al., 2005; Rohaeni et al., 2006). Keuntungan/pendapatan dapat 
didefinisikan sebagai selisih antara penerimaan total biaya dan total pendapatan kotor dapat dinilai dengan nilai $\mathrm{R} / \mathrm{C}$ rationya, yang dirumuskan sebagai berikut :

$$
\Pi=\mathrm{TR}-\mathrm{TC}
$$

Dimana:

$\Pi=$ Keuntungan usaha sapi perah dan jagung/tahun (benefit)

$\mathrm{TR}=$ Penerimaan sapi perah dan jagung/ tahun (Total Revenue)

$\mathrm{TC}=$ Biaya produksi usaha sapi perah dan jagung/tahun (Total Cost)

Diketahui dari berapa besar penerimaan yang diperoleh, setiap rupiah yang dikeluarkan oleh peternak dapat dilihat dari rasio penerimaan terhadap biaya. Perhitungan dilakukan dengan menggunakan rumus umum ekonomi:

$$
\mathrm{R} / \mathrm{C} \text { rasio }=\mathrm{TR} / \mathrm{TC}
$$

Dimana :

$\mathrm{R} / \mathrm{C}=$ Imbangan penerimaan dan biaya produksi/tahun

$\mathrm{TR}=$ Pendapatan/tahun (Total Revenue)

$\mathrm{TC}=$ Biaya total/tahun $($ Total Cost $)$

Jika R/C > 1, usaha layak, jika R/C < 1, usaha tidak layak dan jika $\mathrm{R} / \mathrm{C}=1$ usaha tidak untung dan tidak rugi (impas). Untuk menelaah kelayakan apakah usaha sapi perah dan jagung dapat dilanjutkan atau tidak oleh peternak yang tentunya dapat disesuaikan dengan kemampuan dan modal usaha masing masing peternak. Pendapatan peternak yang di peroleh dapat dibandingkan antara biaya produksi dan pendapatan kotor per tahun. Analisis pembiayaan digolongkan ke dalam biaya tetap (fixed cost) dan biaya tidak tetap (variable cost). Setiap pengeluaran biaya produksi dapat dihitung, apabila ada perubahan yang terjadi, pada penambahan biaya, kerugian peternak yang mengalami kematian ternak dan gagal panen. Analisis kelayakan usaha dapat dilakukan secara parsial, indikator analisis yang dipakai R/C ratio Sekarwati (2002). Pertambahan penerimaan bersih dengan tambahan biaya variabel dari setiap perlakuan usaha sapi perah dan usaha jagung sudah banyak dilakukan oleh setiap peternak (Rusdiana et al., 2019).

\section{HASIL DAN PEMBAHASAN}

\section{Kondisi Umum Wiayah Penelitian}

Kecamatan Lembang Kabupaten Bandung Barat, Propinsi Jawa Barat, Indonesia. Kabupaten Bandung Barat memiliki 16 Kecamatan dan 165 Desa. Pada tahun 2017, jumlah penduduk mencapai 1.616.203 jiwa yang

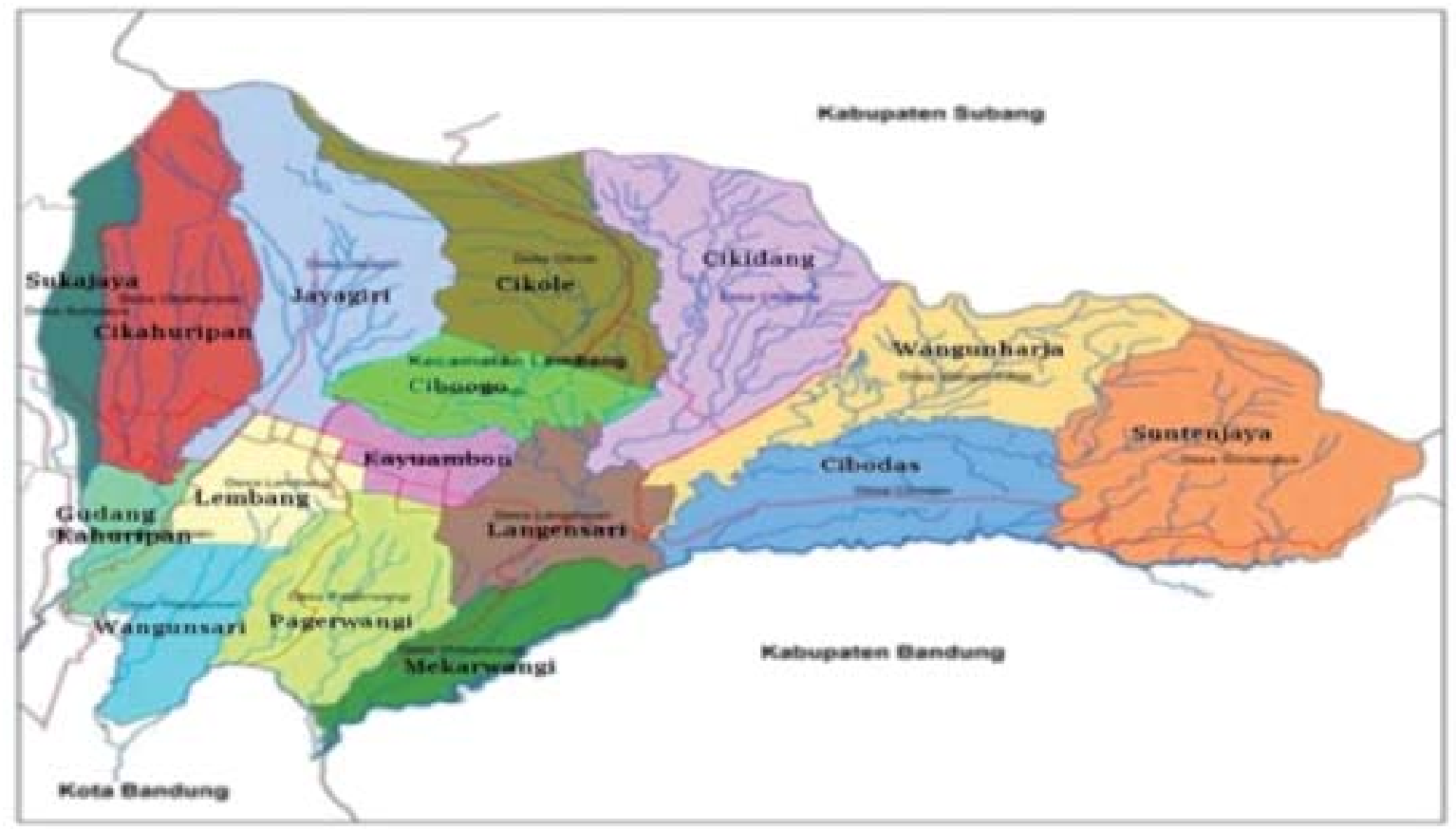

Gambar 1. Peta Geografik 16 Desa, di Kecamatan Lembang, Kabupaten Bandung Barat (Situs Resmi Pemerintah Kabupaten Bandung Barat, 2020) 
tersebar di wilayah seluas $1.305,77 \mathrm{~km}^{2}$ dengan tingkat kepadatan penduduk 1.238 jiwa $/ \mathrm{km}^{2}$. Lingkungan biofisik adalah lingkungan sekitar penduduk yang terdiri dari komponen biotik dan abiotik yang berhubungan dan saling memengaruhi untuk kehidupan perekonmian penduduknya. Komponen biotik merupakan ternak sapi perah yang diusahakan oleh peternak sebagai mahluk hidup, kemudian adanya air, lahan pertanian, perkebunan dan tenaga kerja peternak sebagai sumber daya lokal, sedangkan kualitas lingkungan biofisik sangat baik untuk usaha sapi perah dan usaha tanaman pangan, sehingga saling berinteraksi antar komponen-komponen secara langsung dan seimbang. Artinya kondisi biofisik dan lingkungan wilayah Kecamatan Lembang berpotensi untuk pertumbuhan ekonomi dan perkembangan usaha sapi perah dan usaha pertanian

\section{Kepemilikan Lahan Pertanian dan Sapi Perah}

Kepemilikan sapi perah dapat dipengaruhi dengan luas lahan yang dimiliki oleh setiap peternak. Lahan sebagai daya dukung untuk melakukan aktivitas kerja peternak. Selain untuk pengembangan usaha sapi perah juga usaha pertanian. Hubungan antara jumlah sapi dan luas lahan pekarangan sangat berpengaruh pada kemampuan peternak dalam penambahan skala usaha. unruk meningkatkan kepemilikan sapi perah, peternak diberikan pelatihan dan wawasan dan cara mengelola usaha sapi perah dan usaha pertanian, oleh Dinas maupun Koperasi. Kondisi iklim dan lingkungan wilayah Kecamatan Lembang, berbukit dan sangat sejuk, sehingga perkembangan sapi perah sangat cocok untuk ditingkatkan. Curah hujan yang sangat cukup memberi peluang untuk tumbuhnya rumput introduksi maupun non introduksi di sekitar lingungan sebagai sumber pakan sapi perah.

Usaha sapi perah di peternak banyak dilakukan di Kecamatan Lembang dalam berbagai skala di antaranya sekala besar, sedang dan kecil, terletak dalam berbagai lokasi geografik dan kepadatan penduduknya. Dukungan sumber daya peternak selain usaha sapi perah juga usaha jagung. Dukungan sumber daya manusia peternak di Kecamatan Lembang cukup optimal, karena pengalaman beternak cukup lama, yakni lebih dari 10 tahun. Menurut Demitria et al. (2006) dan Aman dan Harsita (2019) menyatakan bahwa, sumber daya manusia peternak sebagai penggerak usaha, karena sapi perah mempunyai kemampuan untuk memperbaiki produksi susu tinggi dan dapat meningkatan kesejahteraan peternak. Usaha tanaman pangan yang sering diusahakan adalah sayuran, padi, jagung, dan lainnya. Kepemilikan lahan peternak sangat beragam sesuai dengan kemampuan dan kemauan peternak dalam pengelolaannya. Gambaran umum kepemilikan lahan peternak disajikan pada Tabel 1.

Pada Tabel 1, disajikan rataan kepemilikan luas lahan pertanian di desa di Lembang, Bandung umumnya adalah 0,4 $\mathrm{Ha}$, dan di empat desa sampel tersebut menunjukan di atas rata-rata $>0,4 \mathrm{Ha}$, sehingga kepemilikan lahan pertaniannya lebih luas dari pada rataan lahan pertnaian desa. Lahan pertanian yang banyak diusahakan oleh peternak adalah tanaman padi, jagung, sayuran, dan lainnya, dan limbah hasil pertanian banyak dimanfaatkan sebagai pakan sapi perah. Artinya sangat berpengaruh terhadap ketersediaan pakan untuk sapi perah. Usaha sapi perah dapat ditingkatkan di setiap peternak, karena dukungan dengan adanya kecukupan limbah pertanian yang dihasilkan oleh peternak, sedangkan rataan kepemilikan sapi perah di peternak disajikan pada Tabel.2

Tabel 1. Rataan kepemilikan lahan milik peternak sapi perah (Ha) di Kecamatan Lembang, Bandung Barat, Jawa Barat

\begin{tabular}{lcccr}
\hline $\begin{array}{l}\text { Luas lahan/ } \\
\text { uraian (Ha) }\end{array}$ & Desa Cikahuripan & Desa Cikole & Desa Cikidang & Desa Cibogo \\
\cline { 2 - 5 } & Rataan \pm SD & Rataan \pm SD & Rataan \pm SD & Rataan \pm SD \\
\hline Lahan pertanian & $0,57 \pm 0,028$ & $0,60 \pm 0,030$ & $0,62 \pm 0,031$ & $0,58 \pm 0,029$ \\
Lahan ladang & $0,03 \pm 0,00015$ & $0,03 \pm 0,0015$ & $0,04 \pm 0,002$ & $0,03 \pm 0,0015$ \\
Lahan tegalan & $0,03 \pm \_0,00015$ & $0,03 \pm 0,0015$ & $0,01 \pm \_0,0005$ & $0,03 \pm 0,0015$ \\
Lahan pekarangan & $0,004 \pm 0,0002$ & $0,005 \pm 0,0003$ & $0,006 \pm 0,0003$ & $0,005 \pm 0,0003$ \\
Jumlah & $0,634 \pm 0,159$ & $0,655 \pm 0,164$ & $0,676 \pm 0,170$ & $0,645 \pm 0,161$ \\
\hline
\end{tabular}


Pada Tabel 2, ditunjukkan, bahwa peternak dari setiap desa di Lembang rata-rata mempunyai sapi induk laktasi/bunting yatitu $1,67 \pm 0,444$ dan $1,2 \pm 0,447$ dan sapi induk laktasi $1,67 \pm 0,410$ dan $1,2 \pm 0,308$. Hubungan antara sapi induk bunting, sapi dara bunting, sapi induk laktasi dan sapi kering siap melahirkan sangat berhubungan erat kaitannya dengan perkembangan sapi perah di peternak, selain untuk menghasilkan pedet juga produksi susu. Menurut Muhammad et al. (2014) bahwa, produksi susu sapi perah, umur induk, pedet dan sapi afkir sangat erat hubungannya dengan nilai produksi dan nilai jual. Usaha sapi perah di peternak sangat erat kaitannya dengan latar belakang sosial ekonomi yang berbeda, sehingga kepemilikan sapi perah berbeda dan skala kepemilikannya antara 2-5 ekor/peternak. Namun, ada sebagian peternak memelihara sapi perah anatar 6-12 ekor/peternak. Menurut Nainggolan dan Erniwaty (2017) secara kelayakan ekonomi pada usaha usaha sapi perah, yang dianggap menguntungkan peternak, adalah peternak yang memelihara tiga ekor induk laktasi per peternak.

Dilihat di desa sampel bahwa rataan kepemilikan sapi laktasi lebih dari tiga ekor, kecuali di Desa Cibogo yaitu hanya 2,73 ekor. Jumlah sapi perah dan sapi pedaging di Bandung Barat sebanyak 38 ribu ekor atau sebanyak 200

Tabel 2. Rataan kepemilikan sapi perah pada peternak di Kecamatan Lembang, Bandung Barat, Jawa Barat

\begin{tabular}{lcccc}
\hline Sapi perah (ekor) & $\begin{array}{c}\text { Desa Cikahuripan } \\
\text { Rataan } \pm \text { SD }\end{array}$ & $\begin{array}{c}\text { Desa Cikole } \\
\text { Rataan } \pm \text { SD }\end{array}$ & $\begin{array}{c}\text { Desa Cikidng } \\
\text { Rataan } \pm \text { SD }\end{array}$ & $\begin{array}{c}\text { Desa Cibogo } \\
\text { Rataan } \pm \text { SD }\end{array}$ \\
\hline Sapi induk laktasi/bunting & $1,67 \pm 0,444$ & $1,20 \pm 0,447$ & $1,33 \pm 0,489$ & $1,20 \pm 0,447$ \\
Sapi induk laktasi & $1,20 \pm 0,447$ & $1,67 \pm 0,410$ & $1,20 \pm 0,308$ & $1,33 \pm 0,366$ \\
Sapi induk laktasi kosong & $0,27 \pm 0,410$ & $0,33 \pm 0,308$ & $1,33 \pm 0,3078$ & $0,20 \pm 0,366$ \\
Sapi induk bunting dara & $0,20 \pm 0,366$ & $0,20 \pm 0,366$ & $0,20 \pm 0,366$ & $0,27 \pm 0,410$ \\
Sapi betina muda & $0,27 \pm 0,410$ & $0,20 \pm 0,366$ & $0,27 \pm 0,410$ & $0,33 \pm 0,444$ \\
Sapi pedet betina & $0,40 \pm 0,470$ & $0,40 \pm 0,470$ & $0,33 \pm 0,444$ & $0,27 \pm 0,410$ \\
Sapi pedet jantan & $0,27 \pm 0,410$ & $0,33 \pm 0,444$ & $0,27 \pm 0,410$ & $0,2 \pm 0,366$ \\
Sapi jantan muda & $0,53 \pm 0,502$ & $0,33 \pm 0,444$ & $0,27 \pm 0,410$ & $0,33 \pm 0,444$ \\
Sapi jantan dewasa & $0,20 \pm 0,366$ & $0,20 \pm 0,366$ & $0,27 \pm 0,410$ & $0,20 \pm 0,366$ \\
Jumlah & $5,00 \pm 3,557$ & $4,07 \pm 3,623$ & $4,07 \pm 3,557$ & $4,13 \pm 3,621$ \\
\hline
\end{tabular}

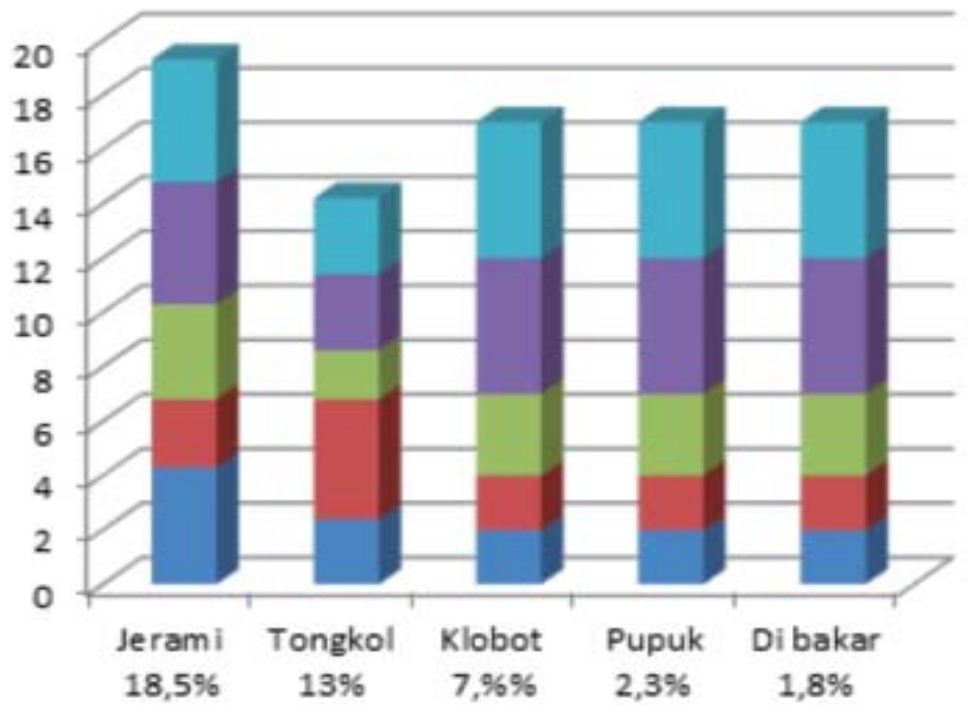

$=\mathrm{N}-100$

Desa Cikahuripan

Desa Cikole

nesa Cikidang

Desa Cibogo

Gambar 2. Rataan pemanfaatan limbah tanaman jagung (0,5 ha) oleh peternak sapi perah di Kecamatan Lembang, Bandung Barat 
ribu ekor merupakan sapi milik anggota KPSBU (Ridwan dan Murdaningsih, 2019). Tinggi rendahnya produksi susu sapi perah yang dihasilkan oleh setiap peternak tergantung pada pemberian pakan yang berkualitas dan jumlah induk sapi perah laktasi dan manajemen pemeliharaan.

\section{Hasil Limbah Produksi Jagung Untuk Pakan}

Berdasarkan hasil survai dengan peternakpeternak sebagai responden diketahui bahwa potensi limbah tanaman jagung yang dimanfaatkan sebagai pakan sapi perah dapat menunjang produksi susu dan pertumbuhan sapi perah. Hampir semua peternak di Kecamatan Lembang Kabupaten Bandung Barat sudah berpengalaman memberikan limbah dari tanaman jagung sebagai pakan sapi perah. Sehingga limbah jagung tidak banyak terbuang dengan begitu saja, karena juga dapat digunakan untuk pupuk tanaman. Rata-rata pemanfaatan jerami jagung sebagai pakan sapi perah peternak, disajikan pada Gambar 2 .

\section{Produksi Susu dan Penjualan Hasil Usaha Sapi Perah}

Usaha peternakan sapi perah sudah cukup lama berlangsung, walaupun sebagian peternak dalam pemeliharaan sapi perah ada yang tidak sesuai dengan kondisi lingkungan. Pelaku usaha sapi perah saling menginformasikan bila terjadi fluktuasi harga susu sapi perah, baik itu harganya naik atau pun turun, juga bertukar informasi tentang adanya pemesanan susu dari luar wilayah. Bertambahnya minat peternak untuk usaha sapi perah, membuat suatu wilayah akan banyak dikunjungi oleh pengusaha atau pebisnis sapi perah dari luar Kabupaten Bandung atau bahkan dari luar Propinsi Jawa Barat. Kecamatan Lembang dapat dijadikan sebagai wilayah kantong sapi perah yang dapat memenuhi kebutuhan konsumen sapi perah, baik dari dalam maupun dari luar wilayah kecamatan. Harga jual hasil produksi sapi perah, dapat meningkatkan perekonomian peternak dan nilai usaha peternakan para peternak. Tinggi rendahnya nilai jual suatu hasil produksi sapi perah dan produksi susu sapi perah, dapat dilihat dari kuantitas dan kualitas serta bobot badan sapi perah (Hertanto et al., 2012). Menurut Barokah (2009) untuk meningkatkan produksi susu sapi perah supaya tetap tinggi, peternak perlu pemberikan pakan yang berkualitas baik, sesuai dengan kebutuhan ternaknya.

Produksi susu sapi perah yang dihasilkan oleh setiap induk laktasi hampir sama. Kesamaan hasil produksi setiap induk laktasi, kemungkinan karena pakan yang diberikan hampir sama, berupa dedak, konsentrat, onggok, ampas tahu, jerami jagung, jerami padi,

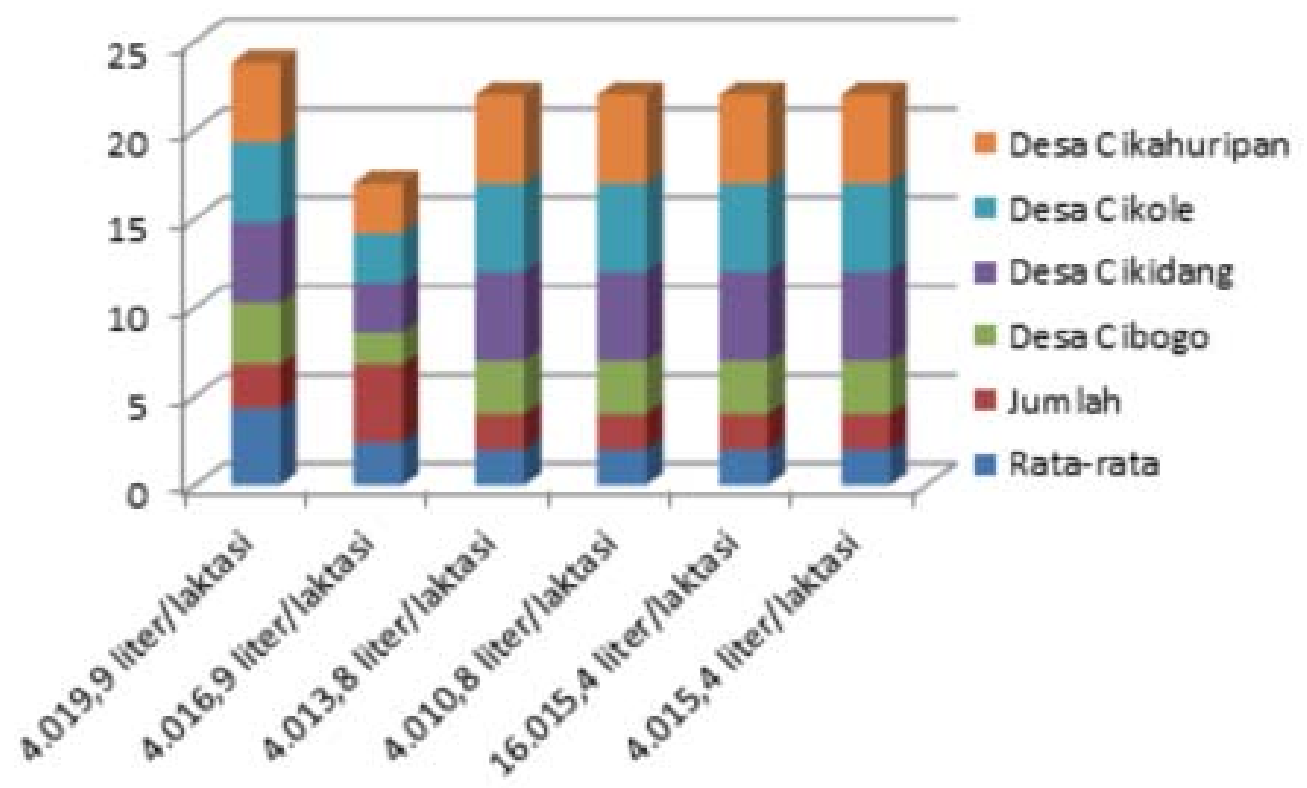

Gambar 3. Produksi susu sapi perah selama laktasi di peternak di Kecamatan Lembang, Bandung Barat 
pakan hijauan, limbah hasil pertanian dan limbah pertanian lainnya. Rata-rata produksi susu sapi perah yang dihasilkan oleh setiap induk sapi perah laktasi di peternak di setiap desa yaitu: Desa Cikahuripan sebanyak 13,18 L/hari/ekor, Desa Cikole sebanyak 13,17 L/hari/ ekor, Desa Cikidang sebanyak 13,16 L/ekor/hari dan Desa Cibogo sebanyak 13,15 L/ekor/hari. Menurut Astuti et al. (2010) produksi susu induk laktasi pada peternak masih rendah dengan rata-rata $>12,5 \mathrm{~L} /$ hari/peternak atau rata-rata $375 \mathrm{~L} /$ bulan. Keberlanjutan usaha sapi perah di kelompok peternak mempunyai katagori yang sedang tidak terlalu kondusif untuk menciptakan usaha yang berdaya saing tinggi. Rata-rata produksi susu sapi perah laktasi di peternak disajikan pada Gambar 3.

Menurut Sutanto dan Listiari (2011); Andidyasarim et al. (2016), bila usaha masih berkatagori sedang, masih membutuhkan peran teknologi pakan, infrastruktur, tentunya disesuaikan dengan kebutuhan peternak sapi perah. Rata-rata harga susu yang diterima di KPSBU Lembang sebesar Rp 5.000/L. Rata-rata penjualan pedet sapi perah jantan dan pedet betina umur 4-6 bulan sebanyak 0,7-85 ekor/ peternak/ tahun, dengan rata-rata harga sebesar Rp 5.675.000,-/ekor. Rata-rata penjualan sapi perah jantan dewasa umur 1,2-2,3 tahun sebanyak antara 0,1-15 ekor/peternak/tahun, dengan rata-rata harga sebesar $\mathrm{Rp} 17.950 .000 /$ ekor dan rata-rata penjualan induk sapi perah afkir sebanyak antara 0,1-0,15 ekor/peternak/ tahun, dengan rata-rata harga sebesar $\mathrm{Rp}$ 17.250.000/ekor. Rata-rata nilai jual hasil produksi susu, pedet, jantan dan induk afkir di peternak di Lembang disajikan pada Tabel. 3

\section{Biaya Produksi Usaha Sapi Perah}

Biaya produksi (Cost of Production), biaya yang timbul dari suatu proses produksi pada usaha sapi perah dan usaha tanaman pangan yang disebut dengan manufaktur dalam membuat barang atau jasa yang akan dijual. Biaya ini juga biasa dikenal dengan istilah Kos Manufaktur (Manufacturing Cost). Penghitungan biaya pada usaha sapi perah dan usaha pertanian di peternak memiliki peranan yang sangat penting untuk mengetahui unsur apa saja yang membutuhkan pendanaan serta besaran biaya yang dikeluarkan, sehingga dapat membantu peternak dalam menganalisis ekonomi dan mengevaluasi evaluasi untuk proses produksi yang dilakukan. Biaya produksi pada usaha sapi perah berupa lahan, bibit, kandang, peralatan kandang, obat-obatan, pakan, tenaga kerja, pemasaran dan biaya lainnya. Biaya yang paling besar untuk usaha sapi perah adalah untuk pakan, bibit dan tenaga kerja. Biaya produksi dan harga jual sapi perah dan susu sapi perah dapat dipengaruh oleh kondisi perekonomian wilayah setempat.

Biaya produksi usaha sapi perah dapat dipengaruhi oleh produksi susu yang dihasilkan dan jumlah sapi perah yang dipelihara (Pasaribu et al., 2015). Menurut Santosa et al. (2013) bahwa, biaya pakan pada usaha sapi perah dapat mencapai $62,5 \%$ dari total biaya produksi. Biaya tidak tetap yang dikeluarkan oleh peternak meliputi biaya pakan, inseminasi buatan/IB, hormon, peralatan kandang, obat-obatan dan biaya yang tidak terduga. Menurut Andriati dan Sudana (2007), biaya produksi yang dikeluarkan meliputi biaya tetap dan biaya variable. Biaya tetap yang meliputi penyusutan ternak, dan penysusutan kandang, sedangkan biaya variabel, meliputi biaya pembelian pakan, tenaga kerja, obat-obatan, dan biaya yang tidak terduga. Para peternak memaksimalkan biaya produksi

Tabel 3. Rata-rata hasil penjualan produksi sapi perah di peternak di Kecamatan Lembang, Bandung Barat

\begin{tabular}{lccccc}
\hline Desa & $\begin{array}{c}\text { Susu sapi } \\
\text { perah }(\mathrm{Rp})\end{array}$ & $\begin{array}{c}\text { Pedet } \\
(\mathrm{Rp})\end{array}$ & $\begin{array}{c}\text { Jantan } \\
(\mathrm{Rp})\end{array}$ & $\begin{array}{c}\text { Induk afkir } \\
(\mathrm{Rp})\end{array}$ & $\begin{array}{c}\text { Jumlah } \\
(\mathrm{Rp})\end{array}$ \\
\hline Cikahuripan & 20.099 .500 & 4.600 .000 & 2.845 .500 & 1.654 .000 & 29.199 .000 \\
Cikole & 20.084 .500 & 4.883 .250 & 2.632 .500 & 2.242 .500 & 29.842 .750 \\
Cikidang & 20.069 .000 & 4.632 .000 & 2.542 .500 & 1.635 .500 & 28.879 .000 \\
Cibogo & 20.054 .000 & 4.074 .000 & 2.662 .500 & 1.987 .500 & 28.778 .000 \\
Jumlah & 80.307 .000 & 18.189 .250 & 10.683 .000 & 7.519 .500 & 116.698 .75( \\
Rata-rata & 20.076 .750 & 4.547 .312 .5 & 2.670 .750 & 1.879 .875 & 29.174 .688 \\
\hline
\end{tabular}


pada usaha sapi perahnya dan mengalokasikan faktor produksi dalam penggunaanya yang tidak berlebihan dan sesuai kebutuhan (Rusdiana dan Sejati, 2009). Modal yang digunakan peternak untuk usaha sapi perahnya bersumber dari dana milik sendiri atau keuntungan hasil penjualan susu sapi perah yang dikumpulkan.

Menurut Amam et al. (2019) bahwa, nilai ekonomi yang bisa diperoleh dari produk susu sapi perah lokal lebih menguntungkan jika dibandingkan dengan sapi potong. Kepemilikan sapi perah di setiap desa di Lembang cukup beragam, sehingga pengeluaran biaya produksi sangat berbeda, dan tergantung pada kemampuan modal dan jumlah sapi perah yang dipelihara. Peternak sapi perah tidak menggunakan mesin-mesin modern untuk mengolah pakan, masih menggunakan tenaga kerja peternak mandiri. Biaya penyusutan pada usaha sapi perah di peternak, dapat diartikan sebagai pengalokasian harga suatu aktiva tetap selama masa kegunaannya. Timbulnya biaya penyusutan dapat diakibatkan oleh berkurangnya manfaat suatu aktiva dari waktu ke waktu atau tidak berlaku terhadap aktiva tanah karena harganya yang terus naik setiap tahun. Namun, pada usaha sapi perah dapat dihitung biaya penyusutan kandang dan sapi perah induk produksi atau laktasi setiap tahun.

Setiap perolehan aktiva tetap, selalu ada harga yang dialokasikan untuk mendapatkannya, yaitu, harga perolehan menjadi salah satu faktor yang menentukan seberapa besar pengalokasian nilai penyusutan dalam setiap periode usaha. Penghitungan harga perolehan tidak hanya melihat harga pembelian, namun dapat ditambahkan dengan biaya lain yang ditimbulkan dari perolehan aktiva tersebut. Biaya penyusutan dan biaya produksi dihitung berdasarkan waktu satu tahun. Biaya penyusutan kandang $2 \%$ per tahun dan biaya penyusutan induk sapi laktasi sebesar $2,5 \%$ per tahun. Hal tersebut disajikan pada Tabel 4.

\section{Baya Produksi Usaha Jagung}

Biaya produksi usaha jagung meliputi biaya untuk mengolah lahan, benih, pupuk, tenaga kerja, panen dan pemasaran. Jagung dapat dikembangkan pada agroekosistem lahan kering, lahan sawah, lahan tadah hujan hingga lahan sawah irigasi. Peluang usaha jagung sangat tinggi, di samping kebutuhan untuk pakan unggas juga untuk kebutuhan rumah tangga. Menurut Rohaeni et al. (2006), untuk meningkatkan produksi jagung, perlu penggunaan pupuk yang sesuai dengan kondisi lahan, namun pupuk kandang dapat memperbaiki kesuburan tanah. Produksi jagung yang siap dipanen dijual ke tengkulak, harga jagung di kebun dan harga jagung di pasar sangat berbeda. Peternak menjual harga jagung di kebun lebih rendah, karena peternak tidak mengeluarkan biaya dan tenaga pengiriman ke pasar. Bila peternak menjual jagung ke pasar, peternak mengeluarkan biaya tenaga kerja dan transportasi. Lahan yang digunakan untuk usaha jagung mulai dari 0,5-1,0 ha, namun ratarata peternak mengolah lahan untuk usaha jagung antara 0,2-0,5 ha. Usaha jagung di setiap desa di Lembang dilakukan dalam satu tahun dua kali panen.

Di Kecamatan Lembang hampir semua peternak memiliki usaha budidaya jagung dan para peternak bekerjasama dengan tengkulak desa. Kepercayaan peternak terhadap tegkulak desa sudah dibina cukup lama, sehingga kepercayaan yang telah dibina menjadikan suatu fenomena yang peternak dan tengkulak pertahankan. Artinya kedua belah pihak tidak merasa dirugikan, mereka sama-sama merasa diuntungkan. Perbedaan harga jagung di setiap wilayah pertanian sangat berbeda, tergantung pada lokasi dan wilayahnya, salah satunya di Pulau Madura harga jagung di kebun sebesar

Tabel 4. Rata-rata biaya penysusutan dan biaya produksi usaha sapi perah di peternak di Kecamatan Lembang, Bandung Barat

\begin{tabular}{llll}
\hline \multirow{2}{*}{ Desa } & \multicolumn{3}{c}{ Sapi perah (Rp) } \\
\cline { 2 - 4 } & Penvusutan \pm SD & Produksi \pm SD & Jumlah \pm SD \\
\hline Cikahuripan & $566.525 \pm 0.441$ & $19.276 .300 \pm 0.192$ & $19.842 .825 \pm 0.772$ \\
Cikole & $661.052 \pm 0.427$ & $18.754 .800 \pm 0.653$ & $19.415 .825 \pm 0.652$ \\
Cikidang & $663.825 \pm 0.432$ & $18.819 .300 \pm 0.664$ & $19.483 .125 \pm 0.455$ \\
Cibogo & $671.320 \pm 0.527$ & $18.775 .400 \pm 0.552$ & $19.446 .720 \pm 0.346$ \\
Jumlah & $2.562 .722 \pm 1.732$ & $75.625 .800 \pm 1.768$ & $78.188 .495 \pm 1.673$ \\
Rata-rata & $640.680 .5 \pm 0.253$ & $18.906 .450 \pm 0.872$ & $19.547 .123 .8 \pm 0.542$ \\
\hline
\end{tabular}


Rp 5.000/kg (Prasetyo dan Fauziyah, 2020). Rata-rata lahan yang digunakan untuk usaha jagung antara 0,1-0,5 ha/tahun/peternak. Harga jagung di peternak di setiap desa di Lembang, harganya di tingkat tengkulak sebesar Rp.3.150,-/kg. Tengkulak mengambil sendiri hasil panen jagung dari kebun. Perbedaan harga jagung kemungkinan dipengaruhi oleh pasar dan kebutuhan pakan ternak. Rata-rata produksi jagung dan biaya produksi jagung di Lembang disajikan pada Tabel 5.

Pada Tabel 5, ditunjukkan hahwa, rata-rata biaya peroduksi pada usaha tanaman jagung di masing-masing desa/peternak lebih rendah dari pada hasil produksi jagung dan penjualan jagung. Dalam perhitungan usaha usaha jagung dapat dikatakan utung, bila dilihat dari produksi jagung tinggi, dan harga jagung sesuai dengan kondisi pasar, kemudian biaya produksi yang dikeluarkan rendah, sehingga usaha jagung perlu dipertahankan. Biaya tenaga kerja yang digunakan oleh peternak untuk usaha jagung adalah untuk mengolah lahan, menanam, penyulaman, membersihkan rumput, pemupukan, dan panen.

\section{Kinerja Ekonomi Usaha Sapi Perah dan Jagung}

Kinerja ekonomi peternak usaha sapi perah

Tabel5. Rata-rata produksi jagung, penjualan dan biaya produksi jagung seluas $0,5 /$ ha di Kecamatan Lembang, Bandung Barat

\begin{tabular}{lccc}
\hline Desa & $\begin{array}{c}\text { Produksi jagung } \\
(\mathrm{kg})\end{array}$ & $\begin{array}{c}\text { Hasil penjualan } \\
(\mathrm{Rp})\end{array}$ & $\begin{array}{c}\text { Biaya produksi } \\
\text { per tahun (Rp) }\end{array}$ \\
\hline Cikahuripan & $4.099 .5 \pm 0.872$ & $12.913 .425 \pm 0.270$ & $7.062 .710 \pm 0.084$ \\
Cikole & $4.107 \pm 0.632$ & $12.937 .050 \pm 0,273$ & $6.715 .750 \pm 0.621$ \\
Cikidang & $4.100 \pm 0.221$ & $12.915 .000 \pm 0.271$ & $7.200 .000 \pm 0.202$ \\
Cibogo & $4.098 \pm 0.873$ & $12.908 .700 \pm 0.203$ & $7.516 .350 \pm 0.473$ \\
Jumlah & $16.404 .5 \pm 1.982$ & $40.064 .125 \pm 3.812$ & $28.494 .810 \pm 1.812$ \\
Rata-rata & $4.101 .13 \pm 0.603$ & $10.016 .031 .3 \pm 0.098$ & $7.123 .702 .5 \pm 0.371$ \\
\hline \hline
\end{tabular}

Tabel 6. Analisis ekonomi usaha sapi perah di peternak/tahun di Kecamatan Lembang, Bandung Barat

\begin{tabular}{lrrrr}
\hline \multirow{2}{*}{ Desa } & \multicolumn{4}{c}{ Usaha sapi perah $(\mathrm{Rp})$} \\
\cline { 2 - 5 } & \multicolumn{1}{c}{$\begin{array}{c}\text { Pendapatan kotor } \\
(\mathrm{Rp})\end{array}$} & $\begin{array}{c}\text { Biaya produksi } \\
\text { tahun }(\mathrm{Rp})\end{array}$ & $\begin{array}{c}\text { Pendapatan bersih/ } \\
\text { tahun/ekor }(\mathrm{Rp})\end{array}$ & $\mathrm{R} / \mathrm{C}$ \\
\hline Cikahuripan & $29.199 .000 \pm 1,335$ & $19.842 .825 \pm 0,772$ & $9.356 .175 \pm 0,212$ & 1,47 \\
Cikole & $29.842 .750 \pm 1,325$ & $19.415 .825 \pm 0,652$ & $10.426 .925 \pm 0,332$ & 1,54 \\
Cikidang & $28.879 .000 \pm 1,336$ & $19.483 .125 \pm 0.455$ & $9.395 .875 \pm 0.431$ & 1,48 \\
Cibogo & $28.778 .000 \pm 1,348$ & $19.446 .720 \pm 0.346$ & $9.331 .280 \pm 0.732$ & 1,47 \\
Jumlah & $116.698 .750 \pm 3,327$ & $78.188 .495 \pm 1,673$ & $38.510 .255 \pm 1,651$ & 1,50 \\
Rata-rata & $29.174 .688 \pm 1,365$ & $19.547 .123,8 \pm 0,542$ & $9.627 .563,88 \pm 0,362$ & 1,50 \\
\hline
\end{tabular}


yang berkalitas baik. Pemberian pakan hijauan peternak diperoleh dengan cara mencari rumput di sekitar lingkungan pemukiman penduduk, kebun dan memanfaatkan limbah pertanian, seperti jerami jagung, kedele, padi dan kulit kacang tanah. Peternak beranggapan bahwa pakan hijauan mudah diperoleh di sekitar lingkungan pemukiman penduduk (Fadhil et al., 2017). Analisis ekonomi usaha sapi perah di peternak di Lembang disajikan pada Tabel 6 .

Pada Tabel 6, ditunjukkan bahwa, setiap pengeluaran usaha sapi perah di masing-masing desa rata-rata tidak sama, tergantung dari cara pemeliharaan dan cara pemberian pakan. Pendapatan dari hasil penjualan produksi susu sapi perah selama satu tahun dihitung berdasarkan satu ekor, apabila peternak mempunyai sapi perah laktasi antara 2-4 ekor, maka dalam perhitungan keuntungan, dikalikan dengan jumlah sapi perah laktasi yang dipelihara oleh setiap peternak. Hasil penelitian Setianti et al. (2015), mengemukakan bahwa pendapatan rata-rata usaha sapi perah adalah Rp 44.077.000/tahun. Keuntungan yang diperoleh di peternak di masing-masing desa adalah hasil produksi susu sapi perah, pedet, jantan hasil pembesaran dan induk afkir yang tidak mampu lagi memproduksi susu dan menghasilkan pedet. Hampir semua peternak menggantungkan hidupnya dari hasil produksi susu sapi perah, pedet dan induk afkir.

Menurut Rianzani et al. (2018) risiko usaha sapi perah, biasanya sapi perah produktif harus menanggung untuk biaya pada sapi non produktif, seperti pedet, induk yang belum berlaktasi. Biaya pakan diasumsikan kedalam biaya tenaga kerja peternak, selama ini peternak tidak pernah menghitung biaya tenaga kerja, karena dianggap sapi perah dan usaha jagung milik sendiri. Setiap pengeluaran usaha jagung di setiap desa sama, dengan luas lahan 0,5 ha, namun produksi yang dihasilkan tidak sama. Tergantung pada pemeliharaan dan cara pemupukannya. Hasil penelitian Rusdiana dan Sutedi (2016) melaporkan bahwa usaha budidaya jagung dengan luas lahan sekitar 0,3 ha, keuntungan peternak sebesar Rp 559.450/panen/ tahun lebih rendah. Pendapatan kotor dari usaha jagung sebesar Rp 15,64 juta/tahun, dengan rata-rata kepemilikan lahan seluas 0,83 ha, pendapatan besih sebesar Rp 5,88 juta/tahun (Rusdiana et al., 2019). Hasil penelitian Rohaeni et al. (2006) mengemukakan bahwa usaha jagung di lahan kering dengan luas lahan 0,3 ha pendapatan bersih sebesar Rp $9.76 \mathrm{juta} / \mathrm{ha} /$ tahun setara dengan Rp 813.333,-/bulan dan nilai $\mathrm{R} / \mathrm{C} 1,88$, lebih tinggi. Ditinjau dari segi biaya untuk usaha jagung relatif sedang, karena pupuk yang digunakan dari limbah sapi perah milik sendiri. Analisis ekonomi usaha jagung di peternak disajikan pada Tabel 7 .

Pada Tabel 7, ditunjukkan bahwa, diversifikasi usaha sapi perah dan jagung dapat menjamin perkembangan populasi sapi perah serta dapat meningkatkan nilai tambah bagi petermak. Bila dilihat dari di masing-masing desa/peternak usaha jagung nilai ekonomi R/C $>1$. Secara tidak langsung perkembangan ekonomi peternak di setiap desa meningkat serta kesejahteraan peternak terjamin. Dukungan pakan untuk perkembangan sapi perah di wilayah Kecamatan Lembang cukup baik, juga pendapatan peternak lebih optimal. Sapi perah dan jagung sebagai komditas utama yang banyak diusahakan oleh peternak. Selain sebagai usaha pokok, tanaman jagung dapat mengoptimalkan penggunaan lahan serta menanggulangi risiko lahan kering karena pada musim kemaru air bekurang setelah panen padi, sehingga kegagalan panen sedikit terkendali.

Tabel 7. Analisis usaha jagung seluas 0,5 ha/tahun, dengan dua kali panen/tahun di Kecamatan Lembang, Bandung Barat

\begin{tabular}{llrrr}
\hline Desa & $\begin{array}{l}\text { Pendapatan } \\
\text { kotor (Rp) }\end{array}$ & $\begin{array}{l}\text { Biaya produksi/ } \\
\text { tahun (Rp) }\end{array}$ & $\begin{array}{l}\text { Pendapatan/ } \\
\text { tahun (Rp) }\end{array}$ & R/C \\
\hline Cikahuripan & $12.913 .425 \pm 0.270$ & $7.062 .710 \pm 0.084$ & $5.850 .715 \pm 0.427$ & 1.83 \\
Cikole & $12.937 .050 \pm 0.273$ & $6.715 .750 \pm 0.721$ & $6.221 .300 \pm 0.162$ & 1.92 \\
Cikidang & $12.915 .000 \pm 0.271$ & $7.200 .000 \pm 0.202$ & $5.715 .000 \pm 0.571$ & 1.80 \\
Cibogo & $12.908 .700 \pm 0.203$ & $7.516 .350 \pm 0.473$ & $5.492 .350 \pm 0.553$ & 1.72 \\
Jumlah & $40.064 .125 \pm 3.812$ & $28.494 .810 \pm 1.812$ & $23.279 .365 \pm 1.763$ & 1.41 \\
Rata-rata & $10.016 .031 \pm 0.098$ & $7.123 .703 \pm 0.501$ & $5.819 .841 \pm 0.665$ & 1.41 \\
\hline
\end{tabular}




\section{SIMPULAN}

Simpulan penelitian ini adalah diversifikasi usaha sapi perah dan jagung dapat meningatkan penghasilan peternak dengan baik. Dukungan pakan dari limbah jerami jagung dapat memenuhi kebutuhan pakan sapi perah seharihari, serta dapat mengurangi biaya produksi untuk pembelian pakan. Diversifikasi usaha sapi perah dan jagung di setiap desa dengan rataan nilai $\mathrm{R} / \mathrm{C}>1$. Diversifikasi usaha sapi perah dan jagung secara ekonomi layak untuk dilanjutkan.

\section{SARAN}

Peternak harus mempertahankan diversifikasi usaha sapi perah dan jagung, karena kondisi lingkungan wilayah tersebut sangat mendukung untuk perkembangan perekonomian peternak. Perlu perbaikan usaha melalui diversifikasi sapi perah dan jagung, agar pendapatan peternak meningkat. Peternak harus fokus pada usahanya, sehingga usaha yang dihasilkan sesuai dengan keinginan peternak. Penyebaran hasil penelitian ini perlu dilakukan oleh pemerintah daerah melalui kelompok peternak, agar semua peternak dapat meningkatkan penghasilnnya.

\section{UCAPAN TERIMA KASIH}

Terima kasih diucapkan kepada inseminator KPSBU Lembang, Bapak drh Dedy yang telah membantu penelitian ini, juga di ucapkan terima kasih kepada para insemiator dan staf KPSBU Lembang yang telah membantu penelitian dan mencari data di peternak, sehingga penelitian ini dapat ditulis dengan baik. Terima kasih banyak atas kerja sama dan bantuannya.

\section{DAFTAR PUSTAKA}

Amam MW, Jadimko, Pradipta Y, Harsita A, Widodo N, Poerwoko MS. 2019. Sumber daya internal peternak sapi perah dan pengaruhnya terhadap dInamika kelompok dan konteks kerentanan. Jurnal Ilmu Peternakan Terpadu 7(1): 192-200.

Amam MW, Harsita A. 2019. Efek domino performa kelembagaan, aspek risiko dan pengembangan usaha terhadap SDM peternakan sapi perah. Jurnal Sains Peternakan 17(1): 5-11.

Andidyasarim D, Setiadi A, Ekowati T. 2016. Efisiensi pemasaran susu segar di Kecamatan Banyumanik, Kecamatan Getasan dan Kecamatan Cepogo. Jurnal Litbang Jawa Tengah 14(1): 1-8. Doi: h t t p s://doi.org/10.36762/ litbangjateng.v14i1.360

Andriati, Sudana W. 2007. Keragaman dan analisis finansial usaha tani padi (Kasus Desa Primatani, Kabupaten Karawang, Jawa Barat. Jurnal Pengkajian dan Pengembangan Teknologi Pertanian 10(2): 106-118. DOI: http://dx.doi.org/10.21082/ jpptp.v10n2.2007.p\%25p

Asmara A, Purnamardewi YL, Lubis D. 2016. Keragaan produksi susu dan efisiensi usaha peternakan sapi perah rakyat di Indonesia. Jurnal Manajemen dan Agribisnis 13(1): 1425.

Astuti M, Widiati R, Suradiningtyah YY. 2010. Production efficiency of smallholder dairy cattle farming (case study on the farmers members of dairy cattle farm of Kaliurang cooperative, Sleman, Yogyakarta) Buletin Peternakan 34(1): 64-69. https://doi.org/ 10.21059/buletinpeternak.v34i1.108

Barokah U. 2009. Strategi pengembangan usaha peternakan sapi perah rakyat di Kabupaten Boyolali. Jurnal Sains Peternakan 7(2): 8086.

Demitria D, Harianto, Sjafri M, Nunung. 2006. Peran Pembangunan Sumberdaya Manusia dalam Peningkatan Pendapatan Rumah Tangga Petani di Daerah Istimewa Yogyakarta. Forum Pascasarjana IPB 33(3): 155-164.

Diwyanto K, Prawiradiputra BR, Darwinsyah. 2002. Integrasi tanaman-ternak dalam pengembangan agribisnis yang berdaya saing berkelanjutan dan berkerakyatan. Wartazoa 12(1): 1-8

Fadhil M, Hartono M, Suharyati S. 2017. Faktor-faktor yang mempengaruhi conception rate sapi perah pada peternakan rakyat di Propinsi Lampung. Jurnal Penelitian Peternakan Indonesia 1(1): 1-7 
Hermawan S. 2012. Dampak sekolah lapang pengelolaan tanaman terpadu terhadap adopsi teknologi, produktivitas dan pendapatan usahatani padi. Jurnal Pengkajian dan Pengembangan Teknologi Pertanian Bogor 16(2): 140-148

Hertanto B, Setya R, Widiati, Adiarto. 2012. Analisis ekonomi usaha sapi perah serta strategi pengembangan pada peternakan rakyat dan perusahaan di daerah rendah. Buletin Peternakan 36(2): 129-140.

Mandaka S, Hutagaol MP. 2005. Analisis fungsi keuntungan, efisiensi ekonomi dan kemungkinan skema kredit bagi pengembangan skala usaha peternakan sapi perah rakyat di KelurahaN Kebon Pedes, Kota Bogor. Jurnal Agri Ekonomi 23(2): 191-208. Doi: http://dx.doi.org/10.21082/jae. v23n2.2005.191-208

Muhammad DS, Suryana, Lehrans RAJ, Wantasen E, Lainawa. 2014. Hubungan antara faktor sosial ekonomi dengan persepsi peternak terhadap pengembangan usaha peternakan sapi perah di Kota Tomohon. Jurnal Zootek 34(2): 39-48. https:// w w w . a c a d e mia.ed u/ 31728622 / hubungan_antara_faktor

Nainggolan RR, Erniwaty. 2017. Pengaruh faktor sosial ekonomi peternak terhadap pola pengelolaan sapi perah di Kecamatan Lembang, Kabupaten Bandung Barat, Jurnal Ilmiah Wahana Bhakti Praja 7(2): 127-138 DOI: https://doi.org/10.33701/ jiwbp.v7i2.96

Pasaribu A, Firmansyah, Idris N. 2015.Analisis faktor-faktor yang mempengruhi produksi susu sapi perah di Kabupaten Karo Propinsi Sumatera Utara. Jurnal Ilmu-Ilmu Peternakan 18(1): 28-35. Doi: https://doi.org/ 10.22437/jiiip.v18i1.2656

Pemerintah Kabupaten Bandung Barat. 2020. Situs resmi Pemerintah Kabupaten Bandung Barat tahun 2009. [Internet]. [diakses tgl, 12 Januari 2021]. https://petakota.blogspot.com/2016/12/peta-kabupatenbandung-barat.html

Prasetyo DD, Fauziyah R. 2020. Efisiensi usahatani jagung lokal di Pulau Madura, Jurnal Agrisciense 1(1): 26-36. http:// joutnal.trunojoyo.ac.id/agriscience
Rianzani C, Kasymir E, Affandi MI. 2018. Strategi pengembangan usaha ternak sapi perah Kelompok Tani Neang Mukti di Kecamatan Air Naningan Kabupaten Tanggamus. Jurnal Ilmu-Ilmu Agribisnis 6(2): 179-186. Doi: http://dx.doi.org/ 10.23960/jiia.v6i2.\%25p

Ridwan M, Fauzi, Murdaningsih D. 2019. Jumlah sapi perah dan sapi pedaging di Bandung Barat mencapai 38 ribu ekor atau sekitar 20 ribu ekor merupakan sapi milik anggota KPSBU. Bandung. Dinas Perikanan dan Peternakan Kabupaten Bandung Barat. [Internet]. [diakses tgl, 12 januari 2021]. Tersedia pada https:// nasional.republika.co.id/berita/nasional

Rohaeni ES, Amali N, Sumanto, Darmawan A, Sabhan A. 2006. Pengkajian integrasi usahatani jagung dan ternak sapi di lahan kering Kabupaten Tanah laut, Kalimantan selatan. Jurnal Pengkajian dan Pengembangan Teknologi Pertanian 9(2): 129-139.

Rusdiana S, Sejati WK. 2009. Upaya pengembangan agribisnis sapi perah dan peningkatan produksi susu melalui pemberdayaan koperasi susu. Jurnal Agro Ekonomi 27(2): 43-51. Doi:http://10.21082/ fae.v27n1.2009.43-51.

Rusdiana S, Adawiyah CR. 2013. Analisis ekonomi dan prospek usaha tanaman dan ternak di lahan perkebunan kelapa. Jurnal Sosial Ekonomi Pertanian dan Agribisnis 10(1): 118-131. DOI: https://doi.org/ 10.20961/sepa.v10i1.14118

Rusdiana S, Sutedi E. 2016. Analisis ekonomi usaha tanaman jagung dan kambing kosta di Kecamatan Carita Kabupaten Pendeglang Banten. Buletin Peteranakan 40(3): 228-236. DOI: https://doi.org/ 10.21059/buletinpeternak.v41i2.18159

Rusdiana S, Soeharsono. 2017. Farmer group performance Bali cattle in East Luwu district: the economic analysis. The International Joural of Tropical Veterinary and Biomedical Research 12(1): 18-29. Doi: https://doi.org/10.21157/ijtvbr.v2i1.8634

Rusdiaana S, Adiati U, Hapsari AAR, Kusumaningrum DA. 2019. Analisis finansiaal usaha sapi perah dengan cara bagi hasil (paro) di peternak. Jurnal of 
Economic Public and Accounting 2(1): 6785. Doi:https://doi.otg./10.31605/jepa/ v.2i1.453.

Rusdiana S, Praharani L. 2020. Analisis usaha sapi perah kembar di Kecamatn Lembang Kabupaten Bandung Barat. Jurnal Veternier 21(2): 319-332. Doi://10.19087/ jveteriner.2020.21.2.319

Santosa SI. Setiadi A, Wulandari R. 2013. Potential analysis of dairy cattle development through agribusiness paradigma in Musuk Sub District of Boyolali Regency. Buletin Peternakan 37(2): 125-135. DoI: https://doi.org/10.21059/ buletinpeternak.v37i2.2431

Setianti C, Ekowati T, Setiadi A. 2015. Analisis profitabilitas usaha sapi perah di kawasan usaha peternakan (Kunak) Kecamatan Pamijahan Kabupaten Bogor. Jurnal Pengembangan PenYuluh Pertanian 11(2): 121-127. DOI: http://dx.doi.org/10.36626/ jppp.v11i21.127

Simamora T. Fuah AM, Atabany A, Burhanuddin. 2015. Evaluation oF technical aspect on smallholder daIry faRm in Karo Regency of North Sumatera. Jurnal Ilmu Produksi dan Teknologi Hasil Pertanian 3(1): 52-58. https://journal. ipb.ac.id/index.php/ipthp/article/view/10814
Soekartawi. 2002. Prinsip Dasar Ekonomi Pertanian Teori dan Aplikasi. Jakarta. PT Raja Grafindo Persada.

Steel RGD, Torrie JH. 2000. Principles and Procedure of Statististics Approach. Mac Graw Hill Book Co. USA. dan Program SPSS. 2009, versi 16.0 for Windows.

Sutanto A, Hendraningsih L. 2011. Analisis keberlanjutan usaha sapi perah di Kecamatan Ngatang Kabupaten Malang. Jurnal Gemma 7(1): 1-12, http:// ejournal.umm.ac.id/index.php/gamma/ article/view/1413

Syukur S, Fenani Z, Nugroho BA, Antara M. 2014. Empowerment of livestick farmer throngh granduate program to build a village on dynamies model: A case stydy in the distriet of Toli-Toli, Central Silawesi. Journal of Natural Science Research 4(2): 107-112.

Wardani TSK, Budiraharjo, Prasetyo E. 2020. Analisis profitabilitas pada peternakan sapi perah "Karunia" Kediri. Animal Agricultural Journal 1(1): 339-357. http:// ejournals-s1.undip.ac.id/index.php/aaj. 